\title{
KEPATUHAN HUKUM KAWASAN DILARANG MEROKOK MENURUT TEORI LAWRENCE M. FRIEDMAN
}

\author{
Oleh \\ Siti Humulhaer*)
}

\begin{abstract}
Abstrak
Kepatuhan atau ketaatan hukum terhadap kaedah-keaedah pada umumnya, telah menjadi pokok permasalahan yang cukup banyak dibicarakan. Seperti yang telah kita ketahui bahwa asap rokok memiliki sifat yang berbahaya bagi orang yang menghisapnya, karena asap rokok mengandung nikotin dan tar yang dapat menyebabkan kecanduan dan dapat menyebabkan terjadinya kanker paru-paru. Di Indonesia terjadi peningkatan konsumsi tembakau selama 30 tahun, yaitu dari 33 milyar batang per tahun pada tahun 1970 menjadi 217 milyar batang pada tahun 2000. Persentase orangdewasa yang merokok meningkat dari 26,9\% pada tahun 1995menjadi 31,5\% pada tahun 2001. Pada tahun 2001, 62,2\% dari pria dewasa merokok, dibandingkan pada tahun 1995, sebanyak 53,4\%. Hanya 1,3\% wanita dilaporkan merokok secara teratur pada tahun 2001 (WHO, 1998). Prevalensi pria dewasa yang merokok di pedesaan juga lebih tinggi daripada perkotaan 167,0\% dibandingkan dengan 58,3\%) dan 73\% dari perokok tersebut tidak berpendidikan formal (Depkes RI 2009). Diperkirakan, konsumsi rokok Indonesia setiap tahun mencapai 199 milyar batang rokok. Akibatnya adalah kematian sebanyak 5 juta orang per tahunnya. Bila hal ini tidak dapat dicegah, maka jumlah kematian akan meningkat dua kali mendekati 10 juta orang per tahun pada 2020. Sasaran kawasan dilarang merokok adalah tempat umum, tempat kerja, tempat proses belajar mengajar, tempat pelayanan kesehatan, arena kegiatan anak-anak, tempat ibadah, dan angkutan umum. Yang kemudian sebagai kompensasi bagi perokok disediakan kawasan khusus untuk merokok yang tempatnya terpisah secara fisik atau tidak bercampur dengan kawasan dilarang merokok, dilengkapi alat penghisap udara atau memiliki sistem sirkulasi udara, dilengkapi asbak atau tempat pembuangan puntung rokok, dapat dilengkapi dengan data dan informasi bahaya merokok bagi kesehatan. Disebutkan pula pada penerapan peraturan, pengawasan dilakukan oleh Perangkat Daerah bersama-sama masyarakat dan/atau organisasi kemasyarakatan, seperti BPLHD, Dinas Kesehatan, Dinas Tramtib dan Limas, Dinas Pendidikan Dasar, Dinas Pendidikan Menengah dan Tinggi, Dinas Tenaga Kerja dan Transmigrasi, Dinas Pariwisata, Dinas Perhubungan, Dinas Bina Mental Spiritual dan Kesejahteraan Sosial, Walikota/Bupati, dan Perangkat Daerah lain sesuai dengan tugas dan fungsi masing-masing.
\end{abstract}

\section{Kata Kunci : Kepatuhan Hukum, Larangan Merokok}

\section{A.PENDAHULUAN}

Di dalam ilmu-ilmu sosial, antara lain di dalam sosiologi, masalah kepatuhan atau ketaatan hukum terhadap kaedahkeaedah pada umumnya, telah menjadi

*) Penulis adalah Dosen Fakultas Hukum Universitas Islam Syekh Yusuf pokok permasalahan yang cukup banyak dibicarakan. ${ }^{1}$

1 Soerjono Soekanto, Suatu Tinjauan Sosiologi Hukum Terhadap Masalah-Masalah Sosial (Bandung: Citra Aditya Bakti, 1989), hlm. 54. 
Seperti yang telah kita ketahui bahwa asap rokok memiliki sifat yang berbahaya bagi orang yang menghisapnya, karena asap rokok mengandung nikotin dan tar yang dapat menyebabkan kecanduan dan dapat menyebabkan terjadinya kanker paru-paru. Dari penelitian telah diketahui bahwa orang yang berperan sebagai perokok pasif (orang bukan perokok yang menghirup asap rokok) memiliki resiko yang lebih besar mengalami gangguan kesehatan akibat rokok daripada orang yang berperan sebagai perokok aktif (orang yang merokok), dan jika hal tersebut dikaitkan dengan kondisi perokok yang tidak memperhatikan kepentingan masyarakat sebagai perokok pasif, maka hal tersebut tentu akan sangat membahayakan masyarakat yang berada pada lingkungan sekitar perokok aktif, terutama apabila terdapat anak-anak yang kemungkinan akan mengalami gangguan pertumbuhan maupun gangguan kesehatan akibat menghirup asap rokok. ${ }^{2}$

Di Indonesia terjadi peningkatan konsumsi tembakau selama 30 tahun, yaitu dari 33 milyar batang per tahun pada tahun 1970 menjadi 217 milyar batang pada tahun 2000. Persentase orang dewasa yang merokok meningkat dari $26,9 \%$ pada tahun 1995 menjadi $31,5 \%$ pada tahun 2001. Pada tahun 2001, $62,2 \%$ dari pria dewasa merokok, dibandingkan pada tahun 1995, sebanyak $53,4 \%$. Hanya $1,3 \%$ wanita dilaporkan merokok secara teratur pada tahun 2001 (WHO, 1998). Prevalensi pria dewasa yang merokok dipedesaan juga lebih tinggi daripada perkotaan $167,0 \%$ dibandingkan dengan $58,3 \%$ ) dan $73 \%$ dari perokok ter-

2 Candra Wiguna, Analisis Kebijakan Kesehatan Mengenai Kawasan Dilarang Merokok (On-line) dapat diunduh di: http://ilmukesmas.com/analisiskebijakan-kesehatan-mengenai-kawasandilarang-merokok/, diakses pada tanggal 8 November 2014, hlm. 1. sebut tidak berpendidikan formal (Depkes RI 2009). Diperkirakan, konsumsi rokok Indonesia setiap tahun mencapai 199 milyar batang rokok. Akibatnya adalah kematian sebanyak 5 juta orang per tahunnya. Bila hal ini tidak dapat dicegah, maka jumlah kematian akan meningkat dua kali mendekati 10 juta orang per tahun pada 2020.3

Dari latar belakang di atas, maka penulis merumuskan masalah adalah sebagai berikut :

1. Faktor-faktor apakah yang melatarbelakangi terjadinya ketidakpatuhan hukum terhadap peraturan perundang-undang kawasan dilarang merokok?

2. Bagaimanakan upaya pemerintah dan masyarakat dalam rangka meningkatkan kepatuhan hukum terhadap peraturan perundang-undangan kawasan dilarang merokok ?

\section{B. PEMBAHASAN}

Peraturan Pemerintah Republik Indonesia Nomor 109 Tahun 2012 Tentang Pengamanan Bahan Yang Mengandung Zat Adiktif Berupa Produk Tembakau Bagi Kesehehatan berdasarkan ayat 11 Mengatakan Bahwa : Kawasan Tanpa Rokok adalah ruangan atau area yang dinyatakan dilarang untuk kegiatan merokok atau kegiatan memproduksi, menjual, mengiklankan, dan/atau mempromosikan Produk Tembakau.

Pasal 49

Dalam rangka penyelenggaraan pengamanan bahan yang mengandung Zat Adiktif berupa Produk Tembakau bagi kesehatan, Pemerintah dan Pemerintah Daerah wajib mewujudkan Kawasan Tanpa Rokok.

3 http://kompasiana.com, 
Pasal 50

(1) Kawasan Tanpa Rokok sebagaimana dimaksud dalam Pasal 49 antara lain:

a. fasilitas pelayanan kesehatan;

b. tempat proses belajar mengajar;

c. tempat anak bermain;

d. tempat ibadah;

e. angkutan umum;

f. tempat kerja; dan

g. tempat umum dan tempat lain yang ditetapkan.

Pasal 51

(1) Kawasan Tanpa Rokok sebagaimana dimaksud dalam Pasal 50 huruf f dan huruf g menyediakan tempat khusus untuk merokok.

(2) Tempat khusus untuk merokok sebagaimana dimaksud pada ayat (1) harus merupakan ruang terbuka yang berhubungan langsung dengan udara luar. ${ }^{4}$

Dari hal tersebut di atas menurut Prof Adi Sulistiyono kebijakan publik adalah tindakan atau keputusan ditetapkan oleh pemerintah, biasanya dalam bentuk peraturan perundang-undangan, untuk memberi solusi atas permasalahan publik yang terjadi dalam masyarakat dan/atau untuk mewujudkan visi dan misi pemerintah dan/atau untuk merealisasikan tujuan yang telah diamanahkan dalam konstitusi atau perundang-undangan dimana penyusunannya dilakukan melalui proses KP, yang kualitasnya dipengaruhi oleh konfigurasi politik, kepentingan sosial dan/atau invertensi ekonomi, 5 bahwa sasaran kawasan dilarang merokok adalah tempat umum, tempat kerja, tempat proses belajar mengajar, tempat pelayanan kesehatan, arena kegiatan

4 https://jdih.kemenkeu.go.id/fullText/ 2012/109 TAHUN2012PP.HTM

5 Adi Sulistiyono, Hukum dan Kebijakan publik, Program Doktor Universitas Trisakti Jakarta, 2015 hlm 5 anak-anak, tempat ibadah, dan angkutan umum. Yang kemudian sebagai kompensasi bagi perokok disediakan kawasan khusus untuk merokok yang tempatnya terpisah secara fisik atau tidak bercampur dengan kawasan dilarang merokok, dilengkapi alat penghisap udara atau memiliki sistem sirkulasi udara, dilengkapi asbak atau tempat pembuangan puntung rokok, dapat dilengkapi dengan data dan informasi bahaya merokok bagi kesehatan. Disebutkan pula pada penerapan peraturan, pengawasan dilakukan oleh Perangkat Daerah bersama-sama masyarakat dan/atau organisasi kemasyarakatan, seperti BPLHD, Dinas Kesehatan, Dinas Tramtib dan Limas, Dinas Pendidikan Dasar, Dinas Pendidikan Menengah dan Tinggi,Dinas Tenaga Kerja dan Transmigrasi, Dinas Pariwisata, Dinas Perhubungan,Dinas Bina Mental Spiritual dan Kesejahteraan Sosial, Walikota/ Bupati, dan Perangkat Daerah lain sesuai dengan tugas dan fungsi masing-masing.

Sanksi dapat berupa peringatan tertulis, penghentian sementara kegiatan atau usaha, pencabutan izin, apabila ditemukan terjadi pelanggaran di suatu kawasan dilarang merokok oleh penanggung jawab maupun pimpinan kawasan tersebut (apabila terbukti membiarkan orang merokok di kawasan dilarang merokok). Demikian pula sanksi akan diberikan kepada orang yang merokok pada kawasan dilarang merokok, seperti yang terdapat dalam Peraturan daerah di DKI Jaya dengan bentuk sanksi sesuai dengan Peraturan Daerah Nomor 2 Tahun 2005 tentang Pe-ngendalian Pencemaran Udara dan/atau sesuai dengan peraturan perundang-undangan.

Yakni terdapat sanksi yang diatur dalam Pasal 41 ayat (2) jo Pasal 13 ayat (1) Perda 2/2005 yakni, setiap orang yang merokok di kawasan dilarang merokok diancam dengan pidana kurungan paling lama 6 (enam) bulan atau denda sebanyak-banyaknya Rp. 50 juta. 
Hal tersebut berkaitan dengan kebijakan publik atau populernya sering disebut sebagai kebijakan pemerintahan, merupakan suatu hal yang umum dijumpai, dan senyatanya adalah suatu gejala yang tidak dapat dihindari. Kebijakan (Policy) umumnya dipahami sebagai keputusan-keputusan yang diambil untuk menangani hal-hal tertentu namun kebijakan bukanlah sekedar keputusan yang ditetapkan ${ }^{6}$ dan dalam organisasi Negara tidak dapat dihindari perumusan kebijakan agar Negara dapat bergerak dinamis. Negarapun menjalankan kekuasaan memaksanya dengan kebijakankebijakan.

Negara yang bersisi berbagai jabatanpun dicirikan dengan adanya kebijakankebijakan agar dapat meraih apa-apa yang dicita-citakan, maka hukum dan kebijakan publik merupakan variable yang memiliki keterkaitan yang sangat erat, sehingga telaah tentang kebijakan pemerintah semakin dibutuhkan untuk dapat memahami peranan hukum saat ini. Kompleksnya persoalan ekonomi. Sosial dan politik merupakan sebab kebutuhannya, serta sangat berperan bagi pemerintah dalam menemukan alternatif kebijakan dan bermanfaat bagi masyarakat. Peran pemerintah dapat semakin menonjol jikalau kita pahami pembangunan itu adalah sesuatu kegiatan yang membawa perubahan. Peraturan hukum adalah salah satu tindakan nyata dalam melakukan kebijakan pemerintah. Oleh karena itu setiap kebijakan pemerintah diwujudkan dalam peraturan hukum maka sangat diperlukan pemahaman fungsi hukum yang luas. Hukum memberikan legitimasi bagi pelaksanaan kebijaksanaan publik dan alat untuk melaksanakan kebijaksanaan, sedangkan kebijakan publik pada umumnya dipahami

6 .Muchlis Hamdi, KEBIJAKAN PUBLIK Proses, Analisis, dan Partisipasi, Galia Indonesia, 2014, hal 36 sebagai salah satu upaya atau tindakan pemerintah yang dibuat dalam rangka melaksanakan tugas-tugas pemerintahannya, dalam wujud pengaturan ataupun keputusan. Pada praktiknya, kebijakan publik merupakan hasil dari proses politik yang dijalankan dalam suatu sistem pemerintahan negara, yang di dalamnya terkandung langkah-langkah atau upaya yang harus dilakasanakan oleh pemerintah selaku penyelnggara negara. Dalam praktiknya, kebijakan publik tidak terlepas dari peran dan fungsi aparat pemerintah yang disebut birokrasi ${ }^{7}$

\section{Faktor-faktor yang melatarbela- kangi terjadinya ketidakpatuhan hukum terhadap peraturan perun- dang-undang kawasan dilarang merokok?}

Pada dasarnya perilaku dan kebiasaan masyarakat sangat sulit untuk diukur, namun kenyataannya perilaku dan kebiasaan tersebut dapat dilihat dan diamati dalam jangka waktu tertentu, baik dalam waktu yang singkat maupun dalam waktu yang cukup panjang. Perilaku tersebut merupakan kumpulan berbagai faktor yang saling berinteraksi. Sering tidak kita sadari bahwa interaksi-interaksi yang terjadi tersebut sangat kompleks sehingga terkadang kita tidak sempat untuk memikirkan kenapa perilaku tersebut dilakukan oleh diri sendiri maupun oleh orang lain.

Setiap warga masyarakat sebenarnya mempunyai kesadaran hukum, oleh karena tidak ada warga masyarakat yang tidak ingin hidup dalam keadaan teratur. Masalahnya adalah sampai seberapa jauh tingkat kesadaran hukum yang ada pada diri warga masyarakat tersebut. Menurut Soejono Soekanto, dasar-dasar daripada

\footnotetext{
7 Sahya Anggara, Kebijakan Publik, Bandung, CV Pustaka Setia, 2014. Hlm 33
} 
kepatuhan masyarakat terhadap suatu kebijakan adalah sebagai berikut: 8

Sebab pertama mengapa warga masyarakat mematuhi kaedah-kaedah adalah karena dia diindoktrinir untuk berbuat demikian. Sejak kecil manusia telah dididik agar mematuhi kaedahkaedah yang berlaku dalam masyarakat. sebagaimana halnya dengan unsur-unsur lain dari kebudayaan, maka kaeddahkaedah telah ada waktu seseorang dilahirkan, dan semula manusia menerimanya secara tidak sadar. Melalui proses sosialisasi manusia dididik untuk mengenal, mengetahui serta mematuhi kaedahkaedah tersebut;

Oleh karena sejak kecil mengalami proses sosialisasi, maka lama-kelamaan menjadi suatu kebiasaan untuk mematuhi kaedah-kaeddah yang berlaku. Memang pada mulanya adalah sukar sekali untuk mematuhi kaedah-kaeddah tadi yang seolah-olah mengekang kebebasan. Akan tetapi, apabila hal itu setiap hari dialami, maka lama-kelamaan akan menjadi sutau kebiasaan untuk mematuhinya terutama apabila manusia sudah mulai mengulangi perbuatan-perbuatanya dengan bentuk dan cara yang sama.

Pada dasarnya manusia mempunyai suatu kecenderungan untuk hidup pantas dan teratur. Akan tetapi apa yang pantas dan teratur untuk seseorang belum tentu pantas dan tertaur bagi orang lain. Oleh karena itu diperlukan patokan tentang kepantasan dan keteraturan tersebut. Patokan itu merupakan pedoman atau takaran tentang tingkah laku dan dinamakan kaedah. Dengan demikian maka salah satu faktor yang menyebabkan orang taat pada kaedah adalah karena kegunaan daripada kaedah tersebut.

Kepatuhan merupakan salah satu sarana untuk mengadakan identifikasi dengan kelompok. Seseorang mematuhi

8 Soerjono Soekanto, Op.Cit., hlm. 54-55. kaedah-kaedah yang berlaku dalam kelompoknya bukan karena dia menganggap kelompoknya lebih dominan dari kelompok-kelompok lainnya, tetapi justru karena ingin mengadakan identifikasi dengan kelompok tadi.

\section{Bagaimanakan upaya pemerintah dan masyarakat dalam rangka meningkatkan kepatuhan hukum terhadap peraturan perundang- undangan kawasan dilarang merokok}

Lawrence M. Friedman dalam bukunya yang berjudul The Legal System A Social Science Perspective, 1975; menyebutkan bahwa sistem hukum terdiri atas perangkat struktur hukum (berupa lembaga hukum), substansi hukum (peraturan perundang-undangan) dan kultur hukum atau budaya hukum. ${ }^{9}$ Ketiga komponen sistem hukum tersebut dapat menjadi acuan berhasil atau tidaknya penegakan hukum. Berkaitan dengan ketidakpatuhan yang terjadi di masyarkat terhadap Peraturan Pemerintah Republik Indonesia Nomor 109 Tahun 2012 Tentang Kawasan Dilarang Merokok, maka komponen struktur ini dapat menjadi salah satu faktor penyebab terjadinya ketidakpatuhan tersebut. Banyak faktor yang mempengaruhi ketidakpatuhan terhadap aturan hokum diantaranya adalah lemahnya pemahaman agama, ekonomi, proses rekruitmen yang tidak transparan dan lain sebagainya. Sehingga dapat dipertegas bahwa faktor penegak hukum memainkan peranan yang penting dalam memfungsikan hukum. ${ }^{10}$ Implementasi peraturan tentang kawasan dilarang merokok di terminal Kampung Rambutan masih belum maksimal, hal ini terlihat dari masih banyaknya pengguna jasa terminal, pedagang maupun sopir yang

9 Saifullah, Refleksi Sosiologi Hukum (Bandung: Refika Aditama, 2007), hlm. 27.

10 Ibid., hlm. 2. 
merokok di kawasan tersebut. Hal ini disebabkan karena lemahnya pengawasan yang dilakukan oleh petugas. Kurangnya sosialisasi dan penegakan peraturan yang tegas dan konsisten oleh pihak yang berwenang, sehingga masyarakat merasa tidak memiliki kewajiban untuk merokok atau tidak merokok pada kawasan tertentu. Dilihat dari segi pengawasan, Petugas Satuan Kerja Perangkat Daerah (SKPD) yang berada di lokasi belum secara maksimal melakukan pengawasan. Dari hasil temuan di lapangan, terkadang petugas membiarkan saja orang yang merokok di kawasan tersebut. ${ }^{11}$

Komponen yang kedua yaitu komponen substansi (peraturan perundangundangan). Kawasan dilarang Merokok sebagai komponen substansi yang bertujuan untuk menurunkan angka kesakitan dan/atau angka kematian dengan cara merubah prilaku masyarakat untuk hidup sehat, meningkatkan produktivitas kerja yang optimal, mewujudkan kualitas udara yang sehat dan bersih bebas dari asap rokok;nmenurunkan angka perokok dan mencegah perokok pemula; mewujudkan generasi muda yang sehat. Namun, masih terdapat kelemahan dalam peraturan tersebut. Dilihat dari segi sanksi, masih terdapat ketidaktegasan dalam pelaksanaannya. Sanksi hanya dilakukan ketika ada operassi secara gabungan yang waktu pelaksanaannya tidak menentu. ${ }^{12}$

Komponen terakhir yakni budaya hukum, budaya hukum adalah suasana pemikiran sosial dan keuatan sosial yang menentukan bagaimana hukum diguna-

11 Suhadi, Agus Martono. Implementasi Peraturan Gubernur DKI Jakarta Nomor 88 Tahun 2010 Tentang Kawasan Dilarang Merokok (Studi di Kawasan Terminal Kampung Rambutan). Jurnal PPKN Universitas Negeri Jakarta, Volume 2, Nomor 4, 2014.Hlm. 6-7.

12 Ibid., hlm. 7-8. kan, dihindari, atau disalahgunakan. Budaya hukum erat kaitannya dengan kesadaran hukum masyarakat. semakin tinggi kesadaraan hukum masyarakat maka akan tercipta budaya hukum yang baik dan dapat merubah pola pikir masyarakat mengenai hukum selama ini. Secara sederhana, tigkat kepatuhan masyarakat terhadap hukum merupakan salah satu indikator berfungsinya hukum. ${ }^{13}$ Pada umumnya masyarakat yang merupakan perokok pasif masih memiliki rasa takut untuk menegur orang yang merokok di kawasan terminal Kampung Rambutan tersebut. Kemudian jarang pula masyarakat langsung melaporkan kepada petugas apabila mendapati orang yang merokok. Mereka lebih baik menghindar atau tutup hidung, karena jika menegur takut menyinggung perasaan orang yang ditegur. ${ }^{14}$

Sebenarnya ada banyak cara yang dapat dilakukan untuk menutupi permasalahan yang mungkin akan timbul. Kemungkinan semua permasalahan yang timbul akan bermuara pada komitmen dalam merencanakan dan melaksanakan suatu kebijakan maupun peraturan. Terlebih dahulu diperlukan sosialisasi dan penyampaian pesan yang baik kepada masyarakat sebagai sasaran akan adanya penerapan atau pelaksanaan suatu kebijakan maupun peraturan. Sosialisasi tersebut diharapkan dapat memberikan pengetahuan dan dapat memberikan gambaran yang jelas tentang peraturan yang akan diterapkan, sehingga masyarakat dapat membentuk sikap dan perilaku yang positif terhadap peraturan tersebut. Oleh karena itu diperlukan komunikasi yang baik antar kelompok, antar organisasi, dan antar individu yang tidak melupakan aspek budaya masyarakat sekitar, yang dapat disampaikan baik melalui

13 Abdurrahman Misno,Op.Cit., hlm. 2.

14 Suhadi, Agus Martono, Op.Cit., hlm. 8. 
media massa, maupun media elektronik yang disampaikan secara jelas.

Setelah itu diperlukan komitmen bersama dalam melaksanakan peraturan. Bukan hanya masyarakat yang menjadi objek penerapan peraturan, tetapi diperlukan juga peran serta dari pihak pemerintah selaku pembuat kebijakan yang seharusnya terlebih dahulu mengetahui dan melaksanakan peraturan dengan sebaik-baiknya, dengan demikian akan terlihat bahwa adanya keseriusan dalam membuat dan melaksanakan kebijakan maupun peraturan yang ada. Selain itu tampak adanya keseriusan dalam memecahkan suatu permasalahan dan dapat menjadi referensi bagi orang lain. Oleh karena itu sangat diperlukan pelaksanaan tugas yang baik dari petugas (dalam hal ini Penyidik Pegawai Negeri Sipil atau PNS) sebagai pengawas dan penegak peraturan. Penyelenggaraan peraturan dan sanksi juga harus dilaksanakan secara tegas dan konsisten. Pada kondisi seperti ini penyelenggaraan peraturan yang tegas dan konsisten juga merupakan salah satu cara yang dapat memberikan perubahan perilaku masyarakat sehingga dapat memberikan efek jera. Tata laksana, pengawasan dan pemberian sanksi harus disesuaikan dengan perundangundangan dan peraturan yang berlaku, oleh karena itu diperlukan pertimbangan yang matang dalam membuat peraturan sehingga tidak menimbulkan ketimpangan dengan peraturan lainnya dan meminimalisir celah terhadap terjadinya pelanggaran.

Integrasi dengan instansi lain juga memiliki peran yang penting dalam melaksanakan dan memastikan kelancaran suatu peraturan maupun kebijakan. Khususnya dalam melaksanakan peraturan tentang kawasan bebas asap rokok, salah satunya dengan pengembangan kebijakan dari sektor produksi rokok maupun pengelola keberadaan rokok yang terkait. Peningkatan cukai dirasa sangat efektif dalam mengurangi pengeluaran biaya untuk bidang kesehatan, selain itu peningkatan cukai juga dapat mengurangi jumlah konsumsi rokok oleh masyarakat. Bila diinjau dari sudut ekonomi; memang industri rokok menyumbangkan dan menjanjikan prospek ekonomi dari besarnya pajak yang diterima negara dan tersedianya lapangan pekerjaan, akan tetapi sumbangan ekonomi yang diberikan dari sektor industri tembakau beserta produk ikutannya tidaklah signifikan dengan tingkat kerugian akibat dampak dari industri tembakaukau tersebut; kontribusi positif dari keberadaan industri rokok di Indonesia terhadap kesejahteraan sosial masyarakat terlihat lebih kecil jika dibandingkan dengan kontribusi negatifnya. Hal ini tampak pada beban cost yang harus ditanggung oleh masyarakat lebih besar daripada benefit yang diterima oleh masyarakat. Konsumsi produk industri rokok sama sekali tidak menguntungkan ditinjau dari segi kesehatan, melainkan merangsang timbulnya berbagai macam jenis penyakit yang merugikan. 15

\section{PENUTUP}

Kepatuhan atau ketaatan hukum terhadap kaedah-keaedah pada umumnya, telah menjadi pokok permasalahan yang cukup banyak dibicarakan. Yakni Belum maksimalnya tindakan petugas pelaksana yang kurang tegas ketika terdapat orang yang merokok dikawasan dilarang merokok dan kurangnya pembinaan yang dilakukan seperti sosialisasi, penyuluhan dan pemberdayaan masyarakat.

Kemungkinan semua permasalahan yang timbul akan bermuara pada komitmen dalam merencanakan dan melaksanakan suatu kebijakan maupun peraturan. Terlebih dahulu diperlukan

15 Rokok: Keutungan Ekonomi, Kebuntungan Kesehatan (On-line) dapat diunduh di: http://kompasiana.com, 
sosialisasi dan penyampaian pesan yang baik kepada masyarakat sebagai sasaran akan adanya penerapan atau pelaksanaan suatu kebijakan maupun peraturan. Sosialisasi tersebut diharapkan dapat memberikan pengetahuan dan dapat memberikan gambaran yang jelas tentang peraturan yang akan diterapkan, sehingga masyarakat dapat membentuk sikap dan perilaku yang positif terhadap peraturan tersebut.

Pemerintah harus benar-benar memikirkan sanksi apa yang tepat untuk si pelanggar sehingga sanksi dapat berlaku secara efektif dan Masyarakat hendaknya memilki kesadaran hukum terhadap suatu peraturan atau kebijakan yang telah dikeluarkan oleh pemerintah.

Disediakannya lokasi tempat khusus untuk merokok diharapkan dapat diadakan agar perokok aktif dapat merokok di kawasan tersebut.

\section{DAFTAR PUSTAKA}

\section{Literatur}

Anggara Sahya, Kebijakan Publik, Bandung, CV Pustaka Setia, 2014.

Hamdi Muchlis, KEBIJAKAN PUBLIK Proses, Analisis, dan Partisipasi, Galia Indonesia, 2014.

Saifullah, Refleksi Sosiologi Hukum (Bandung: Refika Aditama, 2007).

Soekanto Soerjono, Suatu Tinjauan Sosiologi Hukum Terhadap Masalah-MasalahSosial (Bandung: Citra Aditya Bakti, 1989

Sulistiyono Adi, Hukum dan Kebijakan publik, Program Doktor Universitas Trisakti Jakarta, 2015

\section{Peraturan Perundang-undangan}

Peraturan Pemerintah Republik Indonesia Nomor 109 Tahun 2012 Tentang Pengamanan Bahan Yang $\mathrm{Me}$ ngandung Zat Adiktif Berupa Produk Tembakau Bagi Kesehatan

Peraturan Daerah Nomor 2 Tahun 2005 tentang Pengendalian Pencemaran Udara

\section{Sumber lain}

Misno Bambang Prawiro Abdurrahman, Teori Sistem Hukum Friedman (On-line) dapat diunduh di: http://www.scribd.com/doc/1322 30281/Teori-Sistem HukumFriedman

https://jdih.kemenkeu.go.id/fullText/201 2/109TAHUN2012PP.HTM

Rokok: Keutungan Ekonomi, Kebuntungan Kesehatan (On-line) dapat diunduh di: http://kompasiana.com, diakses pada tanggal 8 November 2014.

Suhadi, Agus Martono. Implementasi Peraturan Gubernur DKI Jakarta Nomor 88 Tahun 2010 Tentang Kawasan Dilarang Merokok (Studi di Kawasan Terminal Kampung Rambutan). Jurnal PPKN Universitas Negeri Jakarta, Volume 2, Nomor 4, 2014.

Wiguna Candra, Analisis Kebijakan Kesehatan Mengenai Kawasan Dilarang Merokok (On-line) dapat diunduh di: http:// ilmukesmas. com/ analisiskebijakan kesehatan-mengenaikawasan-dilarang-merokok/, diakses pada tanggal 8 November 2014 